For submission as a short communication to Scottish Journal of Geology

\title{
Pre-Late Devensian high-arctic marine deposits in SW Scotland
}

\author{
J.D. PEACOCK* AND J.D. EVEREST
}

British Geological Survey, Edinburgh EH9 2BN, UK

\begin{abstract}
Synopsis
We present new interpretations of Digital Elevation Model (DEM) data and marine fossils collected from three sites on the Rhins of Galloway which, contrary to recent proposals, suggest that the landforms and deposits of the region do not represent evidence for a readvance during the Lateglacial Period. Rather we suggest that the higharctic fauna found in the region are representative of an earlier, colder part of a Middle Devensian ice-free interval. The predominantly streamlined topography, and distinct lack of identifiable discrete moraine limits argues for only minor, local glacial advances, in combination with widespread rapid retreat across the peninsula at the end of the Lateglacial.
\end{abstract}

\section{Introduction}

The Rhins of Galloway extend SW into the Irish Sea from the southern Scottish mainland. At glacial maximum it has been argued that the peninsula was overridden by the main Scottish Ice Sheet, and during deglaciation a series of ice streams crossed the area, until final disappearance of the ice sheet toward the end of the Lateglacial Period (Charlesworth, 1926, Kerr, 1982, McCabe et al., 1998, Salt \& Evans, 2004, Bradwell et al., 2008 and others). Three decades ago, it was suggested that high-arctic marine deposits formerly seen in two claypits in SW Scotland were possible representatives of the high-arctic Errol Clay Formation of eastern Scotland, and were thus of Devensian lateglacial age (Peacock, 1975). However, following a detailed re-evaluation of NEXTMap DEM data, together with an examination of the geological literature and fossil collections of the British Geological Survey, Edinburgh, it is now thought that this interpretation is incorrect, and that the deposits are in fact probably much older.

Two tills have been identified at sites in the Rhins and adjacent parts of SW Scotland (Figure 1); a locally distributed lower compact calcareous till derived from the north, and a widespread upper red or light brown, noncalcareous till, with erratics from the NE (Figure 1; Geikie and Geikie, 1869; Kerr, 1982). Shell fragments typically occur in the lower till, but are also found within the upper till and in overlying glaciofluvial sand and gravel (Moore, 1850; Stone, 1995; Sutherland, 1993; Shotton and Williams, 1973). The two tills are locally separated by a bed of sand from which, at one site, sand-filled ice cast wedges extend downwards into the lower till (Kerr, 1982).

The area is noteworthy for its streamlined landforms (mainly drumlins), the orientation of many conforming with the derivation of the upper till from the NE (Charlesworth, 1926; Salt and Evans, 2004). However, the last iceflow was towards the SSE along Loch Ryan and into the upper part of Luce Bay (Figure 1; Salt, 2001; Salt and Evans, 
2004). Charlesworth (1926) suggested that kame moraines forming a belt south of Stranraer (his Stranraer Moraine) resulted from a readvance of ice from the north, but the kames, eskers, and dead-ice topography indicate stagnant rather than active ice (Sutherland, 1993). However, the idea that there was a readvance has not been entirely rejected (Salt and Evans, 2004).

\section{Evidence from NEXTMAP digital elevation data}

The overall pattern of palaeo ice-stream flow identified by Salt and Evans (2004) is largely confirmed by NEXTMap imagery, however additional analysis here of the landscape morphology has led to a further development of the interpretation of former ice flow. Apart from the meltwater deposits described by Charlesworth (1926), the landforms comprise three groups in which the features are constructional, formed of till or other glacial deposits:

Group 1: In the Rhins, drumlins up to $50 \mathrm{~m}$ high of varying length and width trend generally NE - SW (Figure 1).

Group 2: Between Loch Ryan and the west side of Luce Bay there are grooved and moulded, low, SSE-trending, streamlined forms up to $2.5 \mathrm{~km}$ long, together with low elongated drumlins such as that at Knockarod [NW 980 650] (800 m long, $200 \mathrm{~m}$ wide and $20 \mathrm{~m}$ high). The NW part of this belt locally transgresses across mounds that may be related to the drumlins of Group 1.

Group 3: East of Loch Ryan and Luce Bay there are drumlins like those of Group 1 in the Rhins, as well as low streamlined forms resembling those of Group 2 above. The direction of orientation of the drumlins changes from NE SW in the north to SSE in the south, where there is an area of bedrock with sharply defined low isolated drumlins. Whether or not Groups 2 and 3 are part of the same suite of landforms is unclear.

There is little evidence for continuous belts of kame moraines as indicated by Charlesworth, excepting for a prominent ridge some $1500 \mathrm{~m}$ long, $250 \mathrm{~m}$ wide and 20 - $40 \mathrm{~m}$ high extending NNE and SSW of High Boreland [NX 087 585]. Without excavation, it is uncertain whether or not this is an end moraine. The occurrence of streamlining south of the ridge (e.g. at Knockarod) indicates that much of this ground is underlain either by till or glacially deformed sediment rather than by meltwater deposits. Moreover, it is probable that the so-called lateral moraines mapped by Charlesworth west of Stranraer are not moraines, but streamlined landforms.

\section{Evidence from former claypits}

Three claypits are noted on the primary 6-inch to 1 mile maps, two near Stranraer being at Clashmahew (Culhorn) [NX 064 593] and Blackparks [NX 066 601] (Figure 1). A third claypit was located at Terally [NX 125 405] in the Rhins. The first was visited by Moore (1850), who collected many complete specimens of the bivalve, Nucula oblonga (see 
Table 1 for synonyms). No shells were recorded by the geological surveyors from the reddish brown boulder clay at Blackparks, but the following were recorded at Clashmahew: Leda truncata, Cardium edule, Cardium norvegicum, Cyprina islandica and the gastropod Natica montacuti (Irvine and Geikie, 1873).

In an important reference concerned mainly with ostracods, the stratigraphy of the Clashmahew claypit was described as follows (Brady et al., 1874):

1. Upper clay mixed with sand, with polished and striated stones and worn flint pebbles, 7 to $8 \mathrm{ft}$ (2.1-2.4 m).

2. Brown clay (thickness very variable).

3. Blue clay rising into hummocks and occasionally intersected by lenticular beds of sand and gravel, with polished and striated stones and worn flint pebbles, 7 to $8 \mathrm{ft}(2.1-2.4 \mathrm{~m})$.

4. Gravel, sufficiently porous to drain the water from the workings

Height of the claypit above the sea $45 \mathrm{ft} O D(12.7 \mathrm{~m})$.

In the above, bed 1 is likely to be entirely glacigenic, probably till. Brady et al. (1874) mention finding Leda arctica, Leda pygmaea and Leda pernula from the brown and blue clay. A few valves were paired, but most occurred as single valves or as fragments. All were slightly decayed. In the earlier of the two BGS collections from Clashmahew, there are fragments of Jupiteria minuta, Astarte? and a large gastropod together with whole valves and fragments of $P$. arctica. Other recorded species (C. edule, Arctica islandica and P. montagui?) are missing. In the second collection, from levels of $15 \mathrm{ft}(4.7 \mathrm{~m})$ and $20 \mathrm{ft}(6.1 \mathrm{~m})$ from the surface, only $P$. arctica is present as juveniles, as well as fragments and complete valves of adults (including one paired). Although slightly decayed, the valves and shell fragments retain the periostracum. It is noteworthy that the shells of the other species are fragmentary and some are eroded and polished. The other shells recorded by Irvine and Geikie were not present in the collections.

The deposit at the former claypit at Terally (Figure 1) was described as 'stiff greyish brown fine clay with few stones, and imperfectly laminated' (Irvine and Geikie, 1872). The clay, which was of limited extent, was said to lie on the 'Lower Boulder Clay', but whether this corresponds to the lower till of Kerr (1982) is unclear. According to Brady et al. (1874), the height above the sea was $50 \mathrm{ft}(13.7 \mathrm{~m})$. Twenty nine adult and juvenile valves of Portlandia arctica from the claypit are preserved in the BGS collections, together with many fragments. Leda pygmaea has also been reported (Brady et al., 1874; Irvine and Geikie, 1872), but was not present in the collection. Some of the valves of $P$. arctica are slightly eroded, but most are intact and retain the periostracum. However, as at Clashmahew, there is a slight chalkiness that renders the shells fragile and unsuitable for radiocarbon dating. 


\section{Discussion and conclusions}

The orientation and distribution of drumlins and streamlined landforms on the Rhins of Galloway support the conclusion that, following stagnation of ice flowing SW in the Rhins, the latest ice-movement was strongly towards the SSE. There is little dating evidence from the area, excepting that all the sites lie well within the limit of the Last Glacial Maximum. Fragments of boreo-arctic marine shells from the Big Aird Sandpit [NX 098 602] located in moundy glaciofluvial gravels near Stranraer, have provided radiocarbon dates of $>37 \mathrm{ka}{ }^{14} \mathrm{C} \mathrm{BP},>33 \mathrm{ka}{ }^{14} \mathrm{C} \mathrm{BP}$, and 28,940 $+850 /-770{ }^{14} \mathrm{C}$ BP (outer, middle and inner respectively) (Shotton and Williams, 1973). In view of the sandy sediment (permeable) and the fact that the dates were obtained from fragments of 10 species, some contamination by young carbon is to be expected. Unless special precautions were taken to avoid this during collection, the ages are probably beyond the limit of radiocarbon dating.

In combining the accounts from Clashmahew, it is likely that bed 1 at Clashmahew corresponds to the reddish brown boulder clay mentioned by the Geological Survey at both sites. The lenticular beds of sand and gravel may have been intruded into the blue clay by water under pressure as it was overridden by glacier ice. There is thus evidence for incorporation into a till of a disturbed marine clay with indigenous shells (the $P$. arctica fauna in beds 2 and 3 ) and for reworking into part of the marine clay of an earlier generation of more worn and fragmented, non-arctic species. There is no evidence that the marine clay itself was transported any distance. Excepting for mixing following glacial disruption below the NE-derived till, the deposits at Clashmahew and Terally are of similar lithology and palaeontology, and are almost certainly remnants of the same bed. Whereas the Clashmahew deposit lies within the Stranraer Moraine, that at Terally is situated a few km beyond the apparent southerly limit of the NNW to SSE icemovement (Figure 1).

The above discussion allows the following interpretation.

1. The last ice movement extended into Luce Bay, possibly as far south as Terally. However, there are no end or lateral moraines defining a limit, and it is more likely that the SSE movement follows a change in the location of the centre of ice-dispersal from NE to NNW, rather than a readvance (Salt and Evans, 2004).

2. The glacial overriding at Clashmahew is related to Charlesworth's Stranraer Moraine. This must be set against the fact that the glacial landform system is dominated by landforms of stagnant ice. The preservation of a possible endmoraine at one locality (High Boreland) suggests that there may have been a minor forward movement locally during general ice retreat or stagnation. 
3. The arctic marine clay at Clashmahew is older than the upper, reddish brown till derived from the NW, and predates any subsequent ice-movements. That the Terally shells show no evidence of breakage following glacial disturbance does not necessarily mean that the clay was not overridden by the ice that deposited this till, as good preservation of shells in such deposits is known elsewhere (e.g. Peacock and Merritt, 1997). We propose that early deposition followed by later overriding is the likely explanation for the existence of this deposit. It can be speculated that the marine clay was laid down during a colder part of a Middle Devensian ice-free interval, such as that radiocarbon dated to c.30 ka

${ }^{14}$ C BP in western Scotland (Bos et al., 2004).

\section{Acknowledgments}

We thank Mark Dean for access to the collections of the Palaeontology Department, British Geological Survey, Edinburgh. We thank Professor Alistair Dawson for a helpful review, and John Gordon, Emrys Phillips and Tom Bradwell for comments on an earlier version of the manuscript. The paper is published with the permission of the Executive Director of the British Geological Survey (NERC).

\section{References}

BOS, J.A.A., DICKSON, J.H., COOPE, G.R. AND JARDINE, W.G. 2004. Flora, fauna and climate of Scotland during the Weichselian Middle Pleniglacial- palynological, macrofossil and coleopteran investigations. Palaeogeograhy, Palaeoclimatology, Palaeoecology 204, 65-100.

BRADWELL, T., STOKER, M., GOLLEDGE, N., WILSON, C., MERRITT, J., LONG, D., EVEREST, J., HESTVIK, O., STEVENSON, A., HUBBARD, A., FINLAYSON, A., MATHERS H. 2008. The northern sector of the last British Ice Sheet: maximum extent and demise. Earth Science Reviews, 88: 207-226

BRADY, G.S., CROSSKEY, H.W. AND ROBERTSON, D. 1874. The Post-Tertiary Entoma castraca of Scotland. Palaeontographical Society Monograph, London, 1-229.

CHARLESWORTH, J.K. 1926. The readvance, marginal kame moraine of the south of Scotland, and some later stages of retreat. Transactions of the Royal Society of Edinburgh 55, 25-50.

GEIKIE, A. AND GEIKIE, J. 1869. Ayrshire: Southwestern District. Memoir of the Geological Survey: Scotland. Explanation of Sheet 7. Murray and Gibb, Edinburgh.

IRVINE, D.R. AND GEIKIE, A. 1872. Wigtownshire - Mull of Galloway. Memoir of the Geological Survey: Scotland. Explanation of Sheet 1. Murray and Gibb, Edinburgh.

IRVINE, D.R. AND GEIKIE, A. 1873. Western Wigtownshire. Memoir of the Geological Survey: Scotland. Explanation of Sheet 3. Murray and Gibb, Edinburgh.

KERR, W.B. 1982. Pleistocene ice movements in the Rhins of Galloway. Transactions of the Dumfries and Galloway Natural History Society, 3rd Series, 55, 25-50.

MCCABE, M. KNIGHT, J. MCCARRON, S. 1998. Evidence for Heinrich event 1 in the British Isles, Journal of Quaternary Science 13, 549-568.

MOORE, J.C. 1850. Notice of the occurrence of marine shells in the till. Proceedings of the Geological Society of London 6, 388 - 389. 
PEACOCK, J.D. 1975. Scottish late- and post-glacial marine deposits. In Gemmell, A.M.D. (ed.) Quaternary Studies in North East Scotland. Department of Geography, University of Aberdeen, 45-48.

PEACOCK, J.D. AND MERRITT, J.W. 1997. Glacigenic rafting at Castle Hill, Gardenstown, and its significance for the glacial history of northern Banffshire, Scotland. Journal of Quaternary Science 12, 283-294.

SALT, K.E. 2001. Palaeo-ice sheet dynamics and depositional settings in south-west Scotland. Unpublished Ph.D thesis, University of Glasgow.

SALT, K.E., AND EVANS, D.J.A. 2004. Superimposed subglacially streamlined landforms of southwest Scotland. Scottish Geographical Journal 120, 133-147.

SHOTTON, F.W. AND WILLIAMS, R.E.G. 1973. Birmingham University Radiocarbon Dates VII. Radiocarbon 15, 451-468.

STONE, P. 1995. Geology of the Rhins of Galloway district. Memoir of the Geological Survey, HMSO, London.

SUTHERLAND, D.G. 1993. Port Logan, in Gordon, J.E. and Sutherland, DG. (eds)Quaternary of Scotland, 593 - 594. Chapman and Hall, London.

\section{Figure Caption}

Figure 1. Interpretation of NEXTMAP digital elevation data in the Rhins and Stranraer area, SW Scotland. Claypits: B, Blackparks; C, Clashmahew, T, Terally. For 1 to 3, see text

Table 1. Synonyms for mollusca referred to in the text

\begin{tabular}{|l|l|l|}
\hline Modern name & Text name & Distribution \\
\hline Polynices montagui? & Natica montacuti & Boreo-arctic \\
\hline Arctica islandica & Cyprina islandica & Boreo-arctic, S of Polar Front \\
\hline Cerastoderma edule & Cardium edule & Boreo-arctic, S of Polar Front \\
\hline C. norvegicum & Laevicardium crassum & Boreo-arctic, S of Polar Front \\
\hline Nuculana pernula & Leda pernula & Boreo-arctic, N from Denmark \\
\hline Yoldiella lenticula & L. pygmaea & Boreo-arctic, N from Lofoten \\
\hline Portlandia arctica & Leda arctica & High-arctic only \\
\hline Portlandia arctica & Leda truncata & High-arctic only \\
\hline Portlandia arctica & Nucula oblonga & High-arctic only \\
\hline
\end{tabular}




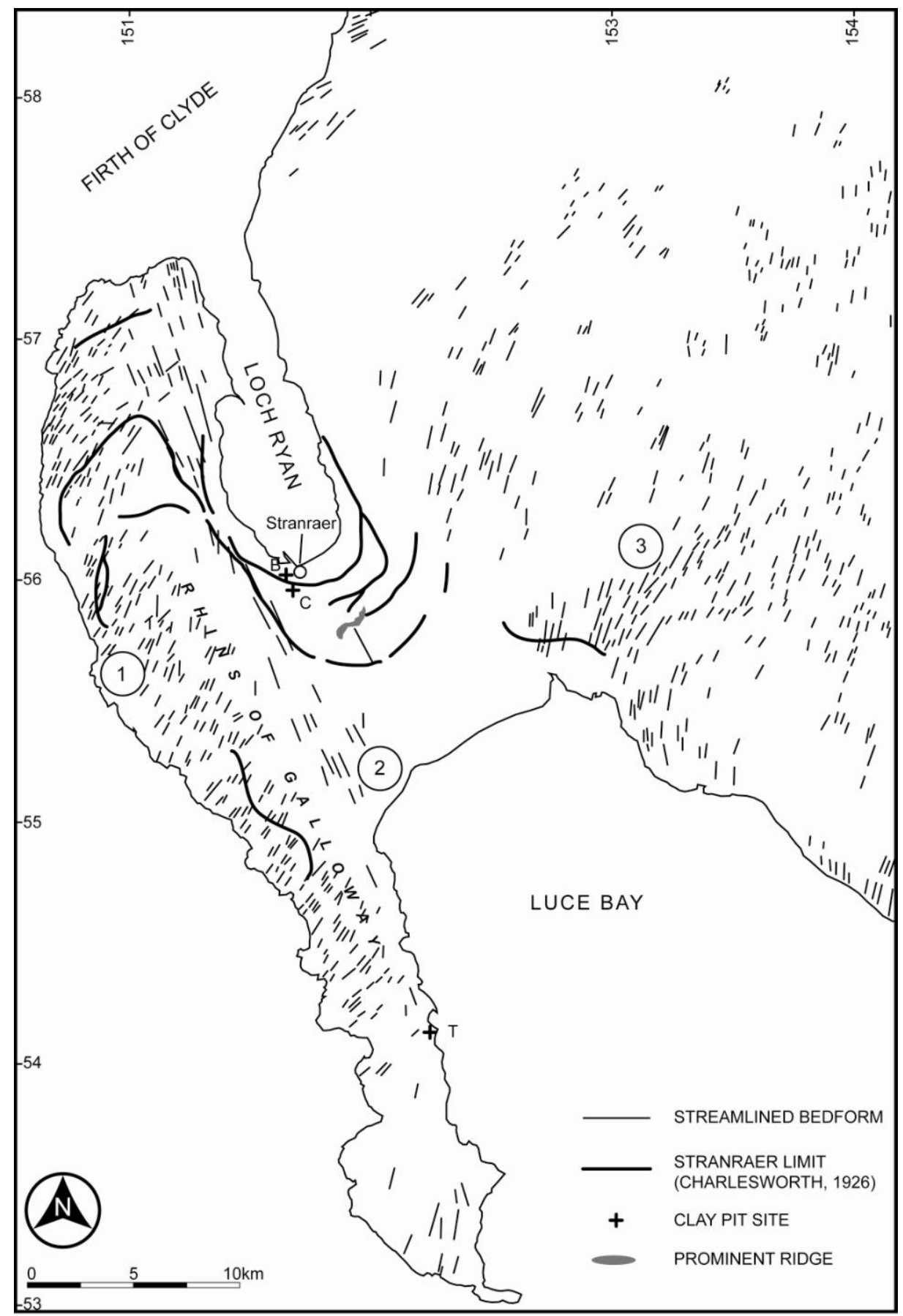

